\title{
DIVERSITY AND EFFICIENCY OF Bradyrhizobium STRAINS ISOLATED FROM SOIL SAMPLES COLLECTED FROM AROUND Sesbania virgata ROOTS USING COWPEA AS TRAP SPECIES ${ }^{(1)}$
}

\author{
Ligiane Aparecida Florentino( ${ }^{(2)}$, Pedro Martins de Sousa ${ }^{(3)}$, \\ Jacqueline Savana Silva ${ }^{(4)}$, Karina Barroso Silva ${ }^{(4)}$ \& Fatima Maria \\ de Souza Moreira ${ }^{(5)}$
}

\begin{abstract}
SUMMARY
The genetic diversity of ten Bradyrhizobium strains was evaluated for tolerance to high temperatures, to different salinity levels and for the efficiency of symbiosis with cowpea plants (Vigna unguiculata (L.) Walp.). Eight of these strains were isolated from nodules that appeared on cowpea after inoculation with suspensions of soil sampled from around the root system of Sesbania virgata (wand riverhemp) in ecosystems of South Minas Gerais. The other two strains used in our analyses as references, were from the Amazon and are currently recommended as cowpea inoculants. Genetic diversity was analyzed by amplifying repetitive DNA elements with the BOX primer, revealing high genetic diversity with each strain presenting a unique band profile. Leonard jar assays showed that the strains UFLA 03-30 and UFLA 03-38 had the highest $\mathrm{N}_{2}$-fixing potentials in symbiosis with cowpea. These strains had more shoot and nodule dry matter, more shoot $\mathrm{N}$ accumulation, and a higher relative efficiency than the strains recommended as inoculants. All strains grew in media of pH levels ranging from 4.0 to 9.0. The strains with the highest $\mathrm{N}_{2}$-fixing efficiencies in symbiosis with cowpea were also tolerant to the greatest number of antibiotics. However, these strains also had the lowest tolerance to high salt concentrations. All strains, with the exceptions of UFLA 03-84 and UFLA 03-37, tolerated temperatures of up to $40^{\circ} \mathrm{C}$. The genetic and phenotypic characteristics of the eight strains isolated from soils of the same region were highly variable, as well as their symbiotic efficiencies, despite their
\end{abstract}

\footnotetext{
(1) Part of the Doctoral Thesis of the first author approved by the Soil Science Graduate Programme of the Federal University of Lavras. Received for publication in October 2009 and approved in May 2010.

(2) Doctor in Soil Science, Federal University of Lavras. E-mail: ligiflorentino@yahoo.com.br

(3) Doctoral student in the Agricultural Microbiology Programme of the Federal University of Lavras. E-mail: pedrinhoconfresa@yahoo.com.br

(4) Undergraduate student, Agronomy, Federal University of Lavras. E-mail: jacsavana@ya hoo.com.br, karikarter@yahoo.com.br

(5) Associate Professor, Federal University of Lavras. E-mail: fmoreira@dcs.ufla.br
} 
common origin. This variability highlights the importance of including these tests in the selection of cowpea inoculant strains.

Index terms: biological $\mathrm{N}_{2}$ fixation, selection, inoculant strains, phenotypic diversity, genotypic diversity.

\title{
RESUMO: DIVERSIDADE E EFICIÊNCIA SIMBIÓTICA DE ESTIRPES DE Bradyrhizobium CAPTURADAS PRÓXIMO AO SISTEMA RADICULAR DE Sesbania virgata USANDO CAUPI COMO PLANTA-ISCA
}

\begin{abstract}
Dez estirpes de rizóbios, sendo oito isoladas de amostras de solos coletadas próximo ao sistema radicular de Sesbania virgata, no Sul de Minas Gerais, e duas recomendadas como inoculante para o caupi (Vigna unguiculata (L.) Walp.) usadas como referências, foram avaliadas quanto a: diversidade genética, eficiência simbiótica em caupi, tolerância a altas temperaturas e concentrações salinas, valores extremos de pH e 15 tipos de antibióticos. A análise de diversidade genética utilizando a técnica do Rep-PCR, com o primer BOX, revelou alta diversidade, pois cada estirpe apresentou perfil único de DNA. O teste de eficiência simbiótica conduzido em vasos de Leonard indicou que as estirpes UFLA 03-30 e UFLA 0338 demonstraram alto potencial em fixar $\mathrm{N}_{2}$ em simbiose com o caupi, proporcionando resultados de matéria seca da parte aérea e dos nódulos, eficiência relativa e acúmulo de $N$ na parte aérea superiores aos das estirpes recomendadas como inoculantes. Todas as estirpes cresceram em meios com valores de pH variando de 4,0 a 9,0. Em relação à tolerância aos antibióticos, foi observado que as estirpes eficientes em fixar $\mathrm{N}_{2}$ em simbiose com o caupi foram as que apresentaram tolerância a um maior número desses compostos. No entanto, estas estirpes mostraram comportamentos semelhantes em relação a tolerância a salinidade, constituindo o grupo de maior sensibilidade. Com exceção das estirpes UFLA 03-84 e UFLA 03-37, as demais toleraram até $40^{\circ} \mathrm{C}$. Embora as estirpes estudadas tenham sido isoladas de solos da mesma região, com exceção das recomendadas para inoculante oriundas da Amazônia, foi observado que elas apresentaram comportamentos distintos quando submetidas aos diferentes testes de diversidade genética, fenotípica e simbiótica, justificando a importância de incluir estes testes no processo de seleção de estirpes simbióticas em caupi.
\end{abstract}

Termos de indexação: fixação biológica de $\mathrm{N}_{2}$, seleção, estirpes inoculantes, diversidade fenotípica, diversidade genotípica.

\section{INTRODUCTION}

Cowpea (Vigna unguiculata (L.) Walp.), commonly known in different regions of Brazil as "feijão-de-corda", "feijão macassar", "feijão-de-praia", "feijão fradinho", "feijão catador", and "feijão miúdo", is a legume with high protein and nutritional values consumed mainly by low-income populations. It is cultivated as subsistence crop in north and northeast Brazil, as well as in countries of South and Central America, Africa, and Asia. This crop adapts well to different environmental conditions and soil types. Lowtechnology cultivation techniques yield a national average of about $500 \mathrm{~kg} \mathrm{ha}^{-1}$, but in the northeast, where more than $90 \%$ of the national production is grown, the average yield is only $317 \mathrm{~kg} \mathrm{ha}^{-1}$ (FreireFilho et al., 2005). In the state of Piaui, one of the leading cowpea producers, the average productivity is $350 \mathrm{~kg} \mathrm{ha}^{-1}$ (Piaui, 2008). Cultivation in low fertility soils is one of the main reasons for low yields (Melo et al., 2005). The cultivation of this legume can benefit from biological $\mathrm{N}_{2}$ fixation (BNF) by rhizobia bacteria.
Studies show that inoculation of cowpea with rhizobia is a viable and promising solution for cowpea growers that could eliminate the use of other $\mathrm{N}$ sources, increasing production levels to up to $1,400 \mathrm{~kg} \mathrm{ha}^{-1}$ (Lacerda et al., 2004; Soares et al., 2006).

Three strains of the genus Bradyrhizobium are currently recommended by the Ministry of Agriculture and Livestock (MAPA) as inoculants for cowpea: UFLA 03-84, INPA 03-11B (Lacerda et al., 2004; Moreira, 2005; Soares et al., 2006), and BR 3267 (Martins et al., 2003). However, given the diversity of Brazilian soil and climate conditions, studies are necessary to select new strains capable of adapting to these conditions and establishing efficient symbiotic relationships with cowpea. Tolerance tests are usually performed in vitro exposing the strains to adverse conditions that mimic those that naturally occur in the soil (Miguel \& Moreira, 2001; Nóbrega et al., 2004; Medeiros et al., 2007; Xavier et al., 2007; Chagas Júnior et al., 2010). To select new inoculant strains for cowpea, which is predominantly cultivated in north and northeast Brazil, adverse conditions such as high 
temperature, high salt concentrations, and low $\mathrm{pH}$ values must be evaluated. Antibiotic tolerance is of particular importance in all soil conditions because it is one of the mechanisms rhizobia can use to overcome the antagonism exerted by other organisms in the soil, including several genera of Actinobacteria, among others (Moreira \& Siqueira, 2006).

This study evaluated the symbiotic efficiency, genetic diversity, and tolerance to various $\mathrm{pH}$ levels, antibiotic concentrations, and salt concentrations in Bradyrhizobium strains isolated from soil samples collected from around the roots of Sesbania virgata in southern Minas Gerais using cowpea as trap plant.

\section{MATERIALS AND METHODS}

\section{Origin of strains and culture characteristics}

Eight Bradyrhizobium strains from the municipalities of Nepomuceno and Ribeirão Vermelho in southern Minas Gerais (Florentino, 2007; Florentino et al., 2009) were analyzed. The strains were isolated from cowpea (trap plant) nodules formed after inoculation with soil samples collected from around the root system of $S$. virgata at a distance of 0 - $10 \mathrm{~m}$ from the plant stem. When grown in medium 79 (YMA) (Fred \& Waksman, 1928; Vincent, 1970) with bromothymol blue at $\mathrm{pH} 6.8$, the characteristics of these strains were typical of the Bradyrhizobium genus, including slow growth with isolated colonies appearing after five to seven days of culture, alkaline reactions in the medium, and medium exopolysaccharide (EPS) production (Jordan, 1982). Three strains were white with an aqueous EPS consistency, while those of the remaining five strains were light yellow with gummy EPS (Table 1). Sample collection locations, soil $\mathrm{pH}$ values, and the indication of the cowpea nodules from which the Bradyrhizobium strains were isolated are shown in table 1 . The two strains isolated in Nepomuceno were obtained from two distinct soil samples, and the six strains isolated from soil samples in Ribeirão Vermelho were obtained from three cowpea plants, i.e., two strains were isolated from distinct nodules of one plant. Two Bradyrhizobium strains isolated from soil in the Amazon, UFLA 03-84 (Semia 6461) and INPA 03-11B (Semia 6463) were also used as references, These strains were approved by Ministry of Agriculture, Livestock and Food Supply of Brazil (MAPA) as cowpea inoculants (Lacerda et al., 2004; Moreira, 2005; Soares et al., 2006) (Table 1).

\section{Genetic diversity}

The genetic diversity of the strains was analyzed by PCR-amplification of repetitive DNA elements with the BOX primer (5'-CTACGGCAAGGCGACGCT GACG-3') (Versalovic et al., 1994). This method has high discrimination power of bacteria at the species, sub-species, and strain levels (Versalovic et al., 1998).

For bacterial DNA extraction, isolated colonies were placed in $1.5 \mathrm{~m} \mathrm{~L}^{-1}$ microtubes with $1 \mathrm{~mL}$ of sterile water and heated to $95^{\circ} \mathrm{C}$ for $10 \mathrm{~min}$. The amplification reaction ( $25 \mu \mathrm{L}$ total volume) consisted of $9.45 \mu \mathrm{L}$ of sterile water, $1.25 \mu \mathrm{L}$ of dNTPs (100 mmol L $\left.{ }^{-1}\right), 5.0 \mu \mathrm{L}$ of $5 \mathrm{X}$ Gitschier buffer, $0.4 \mu \mathrm{L}$ of BSA (20 mg mL-1), $2.5 \mu \mathrm{L}$ of DMSO (100\%), $1.0 \mu \mathrm{L}$ of primer $\left(0.3 \mu \mathrm{g} \mu \mathrm{L}^{-1}\right), 0.4 \mu \mathrm{L}$ of Taq $\left(5 \mathrm{U}_{\mu} \mathrm{L}^{-1}\right)$, and $5.0 \mu \mathrm{L}$ of DNA. Amplification conditions were as follows: initial denaturing cycle at $95{ }^{\circ} \mathrm{C}$ for $7 \mathrm{~min}$; 35 denaturing at $94{ }^{\circ} \mathrm{C}$ for $1 \mathrm{~min}$, annealing at $53^{\circ} \mathrm{C}$

Table 1. pH values of the soil of origin, indication of cowpea plants and nodules from which the Bradyrhizobium strains were isolated, and phenotypic characteristics in medium 79

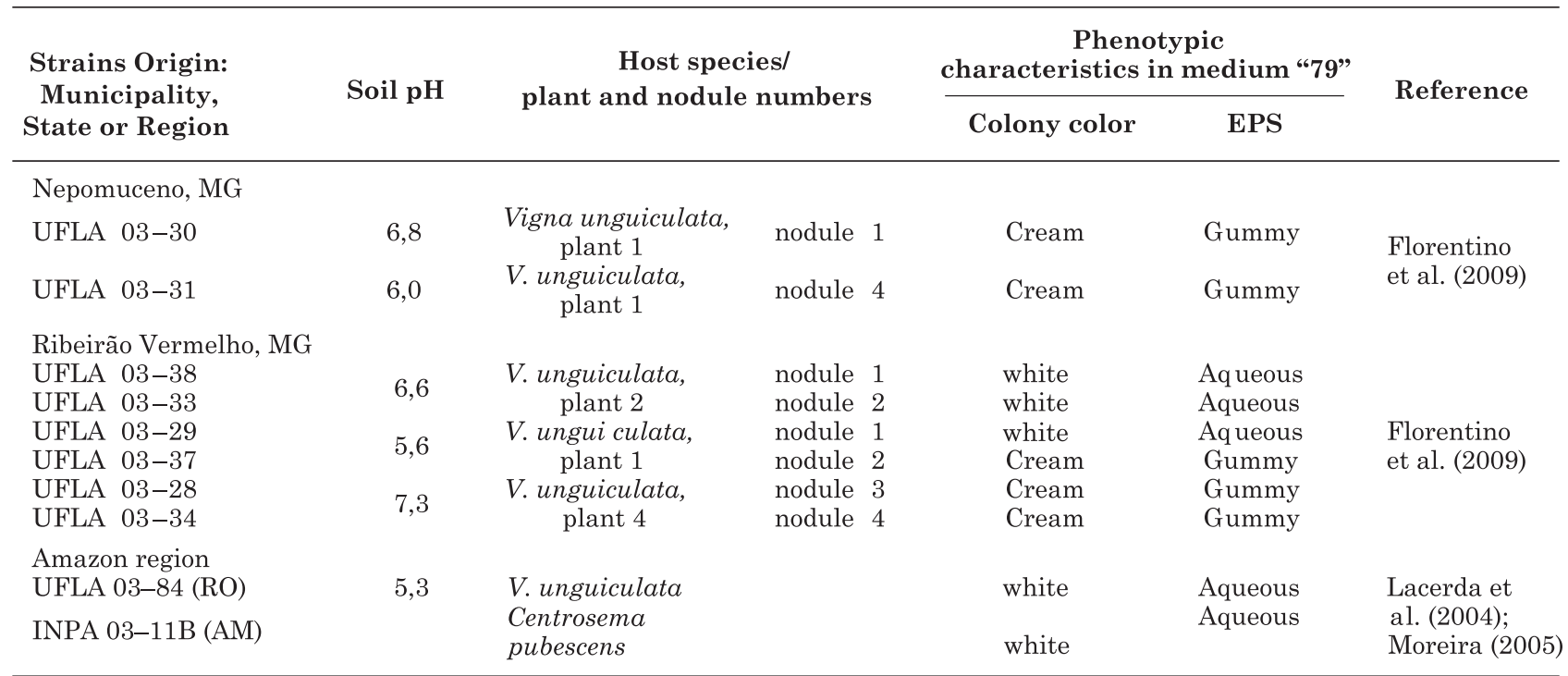


for $1 \mathrm{~min}$ and extension at $65^{\circ} \mathrm{C}$ for $8 \mathrm{~min}$; final extension cycle at $65^{\circ} \mathrm{C}$ for $16 \mathrm{~min}$; and storage at $4^{\circ} \mathrm{C}$. Amplified fragments were electrophoresed in a $20 \times 20 \mathrm{~cm} 1.5 \%$ agarose gel in 0.5X TAE buffer at $70 \mathrm{~V}$ for $16 \mathrm{~h}$ at room temperature. The $1 \mathrm{~Kb}$ Plus DNA Ladder (Invitrogen ${ }^{\mathrm{TM}}$ ) was used to determine the DNA fragment sizes. Following electrophoresis, the gels were stained with ethidium bromide and photographed.

Genetic diversity was analyzed by the presence or absence of polymorphic bands in the gel. A matrix was constructed based on the presence (1) or absence (0) of bands. Matrix data were grouped using the UPGMA (unweighted pair group method using arithmetic averages) algorithm and the Jaccard coefficient with the software NTSYSpc program version 2.10 .

\section{Symbiotic efficiency}

To analyze symbiotic efficiency, ten Bradyrhizobium strains (including the two strains recommended as inoculants) and two negative controls without inoculation were evaluated. One of these negative controls was supplemented with mineral N. The strains recommended for cowpea inoculation, UFLA 03-84 and INPA 03-11B, were used as positive controls.

Experiments were conducted in a greenhouse with cowpea plants cultured in sterile Leonard jars containing a 1:1 mixture of sand and vermiculite (Vincent, 1970). In all treatments, the lower portion of the jars contained Hoagland and Arnon (1950) nutrient solution with a low amount of mineral nitrogen $\left(21 \mathrm{mg} 4 \mathrm{~L}^{-1}\right)$. The mineral $\mathrm{N}$-treated controls were supplemented (per $4 \mathrm{~L}$ ) with $14 \mathrm{mg}$ of $\mathrm{N}$ in $\mathrm{NH}_{4} \mathrm{H}_{2} \mathrm{PO}_{4}, 84 \mathrm{mg}$ of $\mathrm{N}$ in $\mathrm{KNO}_{3}$ and $112 \mathrm{mg}$ of $\mathrm{N}$ in $\mathrm{Ca}\left(\mathrm{NO}_{3}\right)_{2} \cdot 4 \mathrm{H}_{2} \mathrm{O}$. The amounts of other nutrient sources were modified to obtain concentrations similar to the solution without additional mineral N. Seed surfaces were disinfected with $99.8 \%$ ethanol for $30 \mathrm{~s}$ followed by $2 \%$ sodium hypochlorite for $2 \mathrm{~min}$ before planting. The seeds were then washed with sterile water and placed in Petri dishes containing cotton and filter paper moistened with distilled sterilized water for $24 \mathrm{~h}$ prior to sowing.

Four seeds were planted in each pot and inoculated with $1 \mathrm{~mL}$ containing $10^{9}$ cells of the Bradyrhizobium strains in medium 79. The surface of each jar was covered with a fine layer of a sterile 5:1:0.015 (V:V:V) mixture of sand, benzene, and paraffin to avoid contamination. Cultures were thinned three to five days after germination to two plants per pot. During the initial 15 days of cultivation, $1 / 4$ strength Hoagland solution was used; however, due to the increase in the nutritional requirements of the plants, the solution was subsequently used at half strength. This procedure was based on results from previous experiments in our lab showing that the development of cowpea grown in $1 / 4$ strength Hoagland solution was not appropriate. The nutrition solution in the jars was replenished periodically according to the plant uptake rate. The same volume of replenishing solution was added to the jars in all treatments. The statistical design was completely randomized with three replicates for each experimental condition. The plants were grown for 50 days, until they reached the flowering stage. The following variables were analyzed: shoot dry matter (SDM), nodule dry matter (NDM), nodule number (NN), relative efficiency (RE), and shoot $\mathrm{N}$ accumulation (SNA). In addition, bacteria were isolated from four nodules of each plant to confirm that the Bradyrhizobium strains present after culture had the same characteristics as at the time of planting.

For rhizobia isolation, nodule surfaces were disinfected according to Vincent (1970) and ground in Petri dishes containing medium 79 with bromothymol blue, $\mathrm{pH}$ 6.8. Bacteria were cultivated at $28^{\circ} \mathrm{C}$, and all nodules, including those used for isolation, were counted to determine NN. The nodules and cowpea shoots were dried in a forced circulation oven at 65$70^{\circ} \mathrm{C}$ to determine NDM and SDM.

The relative efficiency of each treatment was calculated by the Bergensen et al. (1971) formula, modified as follows: $\mathrm{RE}=(\mathrm{SDM}$ inoculated/SDM with N) x 100, where SDM inoculated is the shoot dry matter of plants inoculated with the tested strain and SDM with $\mathrm{N}$ is the shoot dry matter of plants in the control treatment supplemented with mineral N. In the original formula, SDM of an inoculant strain substituted the SDM supplemented with mineral $\mathrm{N}$. The total $\mathrm{N}$ was analyzed by the semi-micro-Kjeldahl method (Sarruge \& Haag, 1979). SDM, NDM, NN, RE, and SNA data were statistically analyzed with the SISVAR program using the Scott-Knott test at $5 \%$.

\section{Antibiotic tolerance}

Antibiotic tolerance was analyzed aseptically in triplicate using a set of 15 discs with antibiotics at defined concentrations obtained from the Centro de Controle e Produtos para Diagnósticos Ltda (CECON). Bacteria $\left(100 \mu \mathrm{L}\right.$ containing $10^{9}$ cells) were spread on Petri dishes containing medium 79, and three different antibiotic discs were placed in each dish. The discs were equidistant from the others to avoid overlapping zones of inhibition should sensitivity to the antibiotics be observed. The following antibiotics were tested at the indicated concentrations: amoxicillin (AMO), $10 \mu \mathrm{g}$; ampicillin (AMP), $10 \mu \mathrm{g}$; streptomycin (EST), $10 \mu \mathrm{g}$; gentamicin (GEN), $10 \mu \mathrm{g}$; azithromycin (AZI), $15 \mu \mathrm{g}$; clarithromycin (CLA), $15 \mu \mathrm{g}$; erythromycin (ERI), $15 \mu \mathrm{g}$; nalidixic acid (NAL), $30 \mu \mathrm{g}$; chloramphenicol (CLO), $30 \mu \mathrm{g}$; kanamycin (KAN), $30 \mu \mathrm{g}$; rifamycin (RFM), $30 \mu \mathrm{g}$; tetracycline (TET), $30 \mu \mathrm{g}$; vancomycin (VAN), $30 \mu \mathrm{g}$; sulfonamides (SUL), $300 \mu \mathrm{g}$; and Bacitracin (BC), 10 UI. The plates were incubated for seven days at $28^{\circ} \mathrm{C}$. After this period, the presence or absence of an inhibition zone was noted, indicating sensitivity or tolerance, respectively, to the antibiotics 
tested. The results were converted into a binary matrix and a dendrogram was generated using the UPGMA algorithm with the Simple Matching (SM) coefficient program of NTSYSpc version 2.10.

\section{Salt tolerance}

The tolerance of the various Bradyrhizobium strains to different salt concentrations was analyzed in solid medium 79. Bacterial cultures (liquid medium 79) were washed in $0.85 \%$ saline solution prior to plating on medium 79 with different salt concentrations to remove culture medium residue that could result in false positive growth (Trannin et al., 2001; Matsuda et al., 2002; Nóbrega et al., 2004). Aliquots of each bacterial strain $(1 \mathrm{~mL}$ containing $10^{9}$ cells) were transferred to $1.5 \mathrm{~mL}$ sterile micro tubes. Cells were centrifuged at 10,000 rpm for $10 \mathrm{~min}$ at $4{ }^{\circ} \mathrm{C}$. Cells were washed three times by removing the supernatant and resuspending in $1.0 \mathrm{~mL}$ of sterile $0.85 \%$ saline. The bacterial suspensions $(0.1 \mathrm{~mL})$ were spread in triplicate using a Drigalski spatula on medium 79 containing $\mathrm{NaCl}$ at the following concentrations: $86,171,256,342,427,513$, or $684 \mathrm{mmol} \mathrm{L}^{-1}$. These salinity levels are within the range of concentrations utilized in previous studies that evaluated rhizobia salt tolerance (Zerhari et al., 2000; Wei et al., 2008). The bacteria tolerance to $\mathrm{NaCl}$ was evaluated based on the presence (+) or absence (-) of growth after seven days of incubation at $28^{\circ} \mathrm{C}$.

\section{Tolerance to various pH levels}

Tolerance to various $\mathrm{pH}$ levels was tested on medium 79 at the following $\mathrm{pH}$ levels obtained by the addition of $\mathrm{HCl}$ or $\mathrm{NaOH}$ to the media: 4.0, 5.0, 6.0, 7.0, 8.0, and 9.0 (Zerhari et al., 2000; Moschetti et al., 2005; Wei et al., 2008). To assure solidification of the medium, an additional $5 \mathrm{~g}$ of agar were added to plates with media of $\mathrm{pH} 4.0$ and $\mathrm{pH}$ 5.0. The control for this experiment was medium 79 at $\mathrm{pH}$ 6.8. To evaluate bacterial growth, cells were washed, inoculated, and incubated according to the procedure used in the salt tolerance assays.

\section{Tolerance to high temperatures}

To evaluate the bacterial tolerance to high temperatures, cells were washed, inoculated, incubated, and evaluated according to the same procedure used in the salt and $\mathrm{pH}$ tolerance assays. This test was performed in triplicate on solid medium 79. All bacterial strains were incubated at the experimental temperatures of 36,40 and $45^{\circ} \mathrm{C}$, and control cultures were incubated at $28^{\circ} \mathrm{C}$.

\section{RESULTS AND DISCUSSION}

\section{Genetic diversity}

The dendrogram constructed from the analysis of the DNA banding patterns obtained from the amplification of repetitive DNA elements with the BOX-PCR primer revealed that the 10 Bradyrhizobium strains had unique DNA profiles (Figure 1). The maximum degree of similarity (66\%) was observed between strains UFLA 03-33 and UFLA 03-38, and this high degree of genetic diversity supports the (a)

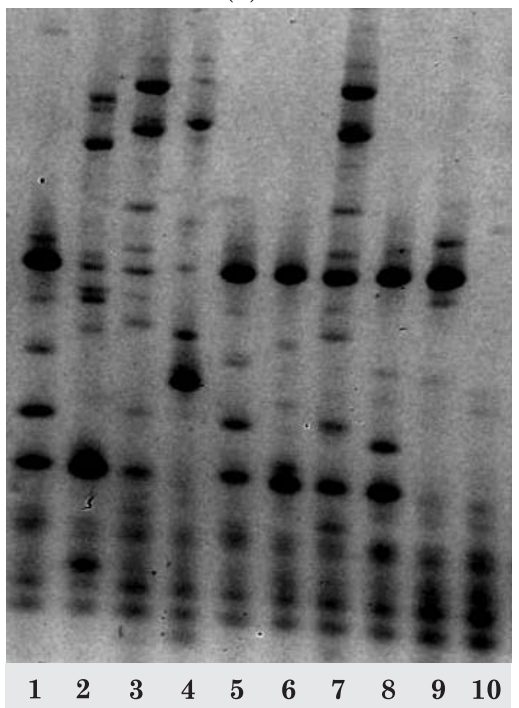

(b)

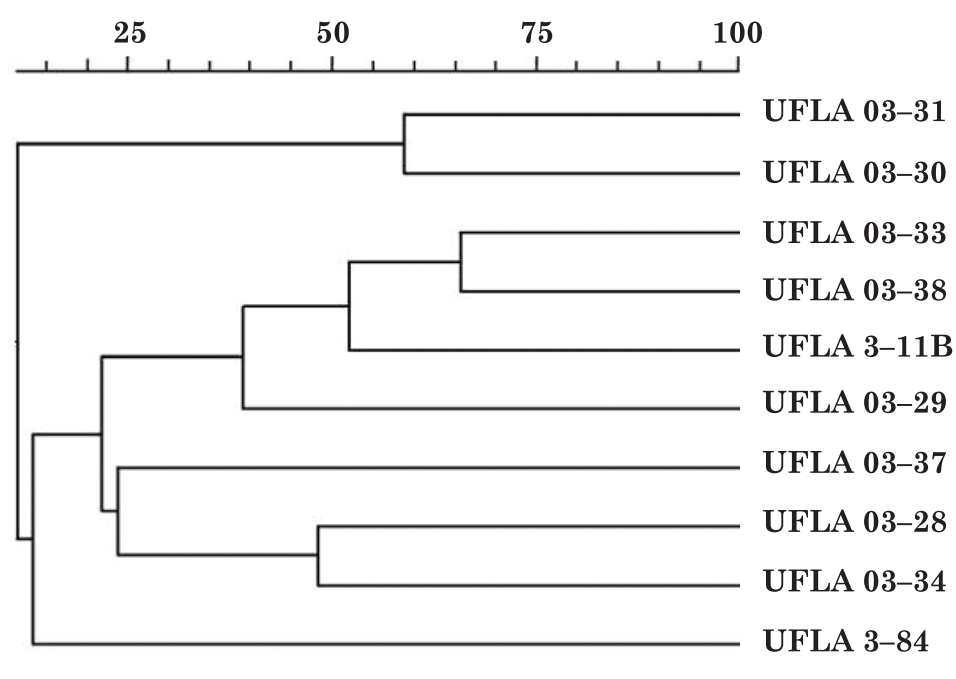

Figure 1. (a) PCR fragments obtained by amplification with the BOX primer using DNA from cowpeaisolated Bradyrhizobium strains (2: UFLA 03-28; 3: UFLA 03-33; 4: UFLA 03-34; 5: UFLA 03-31; 6: UFLA 03-29; 7: UFLA 03-38; 8: UFLA 03-30; 9: UFLA 03-37) and from strains of the genus Bradyrhizobium approved by MAPA as inoculants for cowpea cultivation (1: INPA 03-11B; 10: UFLA 03-84). A dendrogram of the genetic diversity of these strains was constructed using the UPGMA algorithm and Jaccard coefficient (b). 
ability of the BOX primer to discriminate bacterial strains (Versalovic et al., 1998). Other groups analyzing rhizobia strains using REP and ERIC primers also observed high rates of band polymorphism (Laguerre et al., 1996; Laguerre et al., 1997; Chueire et al., 2000). The high diversity in the rhizobia strains analyzed indicates the promiscuous behavior of cowpea, since several species from various rhizobia genera are capable of nodulating this plant species (Moreira, 2008).

\section{Symbiotic efficiency}

An analysis of the variables SDM, NN, NDM, RE, and SNC indicated high variability among the strains studied and the positive controls (Table 2). UFLA 0384 and INPA 03-11B, currently recommended as cowpea inoculants, had higher SDM values than the noninoculated control supplemented with mineral N. The high symbiotic efficiency of these strains with cowpea was observed both in controlled culture conditions, such as in Leonard jars (Lima et al., 2005), and in field experiments (Lacerda et al., 2004; Soares et al., 2006).

Among the eight strains obtained from soil samples near the root system of $S$. virgata, the results of UFLA 03-38 and UFLA 03-30 were the best for all variables analyzed. These two strains also performed better than the currently recommended inoculant strains for cowpea for all parameters except NN, which was lower for UFLA 03-38 than UFLA 03-84. UFLA 0338 and UFLA 03-30 also performed better in SDM, $\mathrm{RE}$, and SNC than the non-inoculated control treatment supplemented with mineral N. These results demonstrate that UFLA 03-38 and UFLA 0330 have a high $\mathrm{N}_{2}$-fixation capacity in symbiosis with cowpea and should be further studied to determine their ability to compete with soil-borne strains and survive edaphic stress because in this study, the symbiotic effectiveness was evaluated in axenic, nutrient-rich conditions.

\section{Antibiotic tolerance}

In the analysis of antibiotic tolerance the Bradyrhizobium strains were separated into four groups (Figure 2). All groups were tolerant to VAN, BC and SUL. Group I contained the largest number of strains, comprising those with tolerance to all antibiotics tested: the two strains currently recommended as cowpea inoculants (INPA 03-11B and UFLA 03-84), a strain with high $\mathrm{N}_{2}$-fixing efficiency in symbiosis with cowpea (UFLA 03-30), as well as UFLA 03-28, UFLA 03-29, and UFLA 0331. The wide range of antibiotic tolerance partially explains the success under field conditions of the inoculant strains currently recommended (Lacerda et al., 2004; Soares et al., 2006), as this tolerance is a possible mechanism to overcome antagonism exerted by other organisms in the soil. Of the 15 antibiotics tested, ten are produced by soil microorganisms, three (SUL, AZI, and NAL) are semi-synthetic or derived from substances produced by microorganisms in the soil, and two are synthetic (AMO and AMP). Some of these antibiotics like AMO, AZI, CLA, ERI and SUL, may also occur in soil due to veterinary use (Regitano \& Leal, 2010).

Group II included UFLA 03-33 and UFLA 03-34, with a similarity of $93 \%$ to group I. The only antibiotic to which the strains in this group were sensitive was RFM. Groups III and IV consisted of a

Table 2. Shoot dry matter (SDM), nodule number (NN) and dry matter (NDM), relative efficiency (RESDM\% in relation to the non-inoculated control supplemented with mineral $N$ ) and shoot nitrogen content (SNC) of cowpea non-inoculated and inoculated with Bradyrhizobium strains of different origins ${ }^{(1)}$

\begin{tabular}{|c|c|c|c|c|c|}
\hline Treatments & SDM & NN/plant & NDM & $\mathbf{R E}$ & SNC \\
\hline & $\mathrm{g} / \mathrm{plant}$ & & $\mathrm{mg} / \mathrm{plant}$ & $\%$ & $\mathrm{mg} /$ plant \\
\hline \multicolumn{6}{|l|}{ Non inoculated } \\
\hline Very low sup. mineral N & $0,09 \mathrm{~h}$ & $0 \mathrm{~d}$ & $0 \mathrm{f}$ & $2,66 \mathrm{~h}$ & $1,87 \mathrm{f}$ \\
\hline With supplement mineral $\mathrm{N}^{(2)}$ & $3,71 \mathrm{~d}$ & $0 \mathrm{~d}$ & $0 \mathrm{f}$ & $100,00 \mathrm{~d}$ & $133,24 \mathrm{c}$ \\
\hline \multicolumn{6}{|l|}{ Inoculated treatments } \\
\hline UFLA $03-84$ & $4,24 \mathrm{c}$ & $491 \mathrm{a}$ & $370 \mathrm{~b}$ & $114,24 \mathrm{c}$ & $171,92 \mathrm{~b}$ \\
\hline INPA $03-11 B$ & $4,61 \mathrm{~b}$ & $298 \mathrm{~b}$ & $390 \mathrm{~b}$ & $124,24 \mathrm{~b}$ & $187,83 \mathrm{~b}$ \\
\hline UFLA $03-38$ & $5,48 \mathrm{a}$ & $269 \mathrm{~b}$ & $440 \mathrm{a}$ & $147,47 \mathrm{a}$ & $261,87 \mathrm{a}$ \\
\hline UFLA $03-33$ & $3,92 \mathrm{~d}$ & $169 \mathrm{c}$ & $110 \mathrm{e}$ & $105,63 \mathrm{~d}$ & $168,59 \mathrm{~b}$ \\
\hline UFLA $03-29$ & $2,25 \mathrm{f}$ & $263 \mathrm{~b}$ & $210 \mathrm{~d}$ & $60,70 \mathrm{f}$ & $104,43 \mathrm{c}$ \\
\hline UFLA $03-37$ & $2,00 \mathrm{~h}$ & $0 \mathrm{~d}$ & $0 \mathrm{f}$ & $5,16 \mathrm{~h}$ & $3,29 \mathrm{f}$ \\
\hline UFLA $03-28$ & $2,50 \mathrm{f}$ & $246 \mathrm{~b}$ & $200 \mathrm{~d}$ & $67,29 \mathrm{f}$ & $102,89 \mathrm{~d}$ \\
\hline UFLA $03-34$ & $3,12 \mathrm{e}$ & $227 \mathrm{~b}$ & $350 \mathrm{~b}$ & $84,00 \mathrm{e}$ & $127,06 \mathrm{c}$ \\
\hline UFLA $03-30$ & $5,70 \mathrm{a}$ & $452 \mathrm{a}$ & $480 \mathrm{a}$ & $153,50 \mathrm{a}$ & $254,35 \mathrm{a}$ \\
\hline UFLA $03-31$ & $1,77 \mathrm{~g}$ & $139 \mathrm{c}$ & $120 \mathrm{e}$ & $47,77 \mathrm{~g}$ & $79,52 \mathrm{e}$ \\
\hline $\mathrm{CV}(\%)$ & 8,23 & 18,87 & 12,64 & 8,23 & 11,9 \\
\hline
\end{tabular}

(1) Values followed by the same letter in a column do not significantly differ based on the Scott-Knott test at $5 \%$; NDM and NN data were adjusted with the square root $(\mathrm{x}+1)$ transformation. ${ }^{(2)}$ Hoagland and Arnon solution (1950) containing 210 mg $\mathrm{N}$ (14 mg as $\mathrm{NH}_{4}^{+}\left(\mathrm{NH}_{4} \mathrm{H}_{2} \mathrm{PO}_{4}\right)$ and $196 \mathrm{mg}$ as $\left.\mathrm{NO}_{3}^{-}\left[\mathrm{Ca}\left(\mathrm{NO}_{3}\right)_{2} \cdot 4 \mathrm{H}_{2} \mathrm{O}\right]\right)$. This solution was used at $1 / 4$ strength for the first 15 days of culture and subsequently at $1 / 2$ strength. 


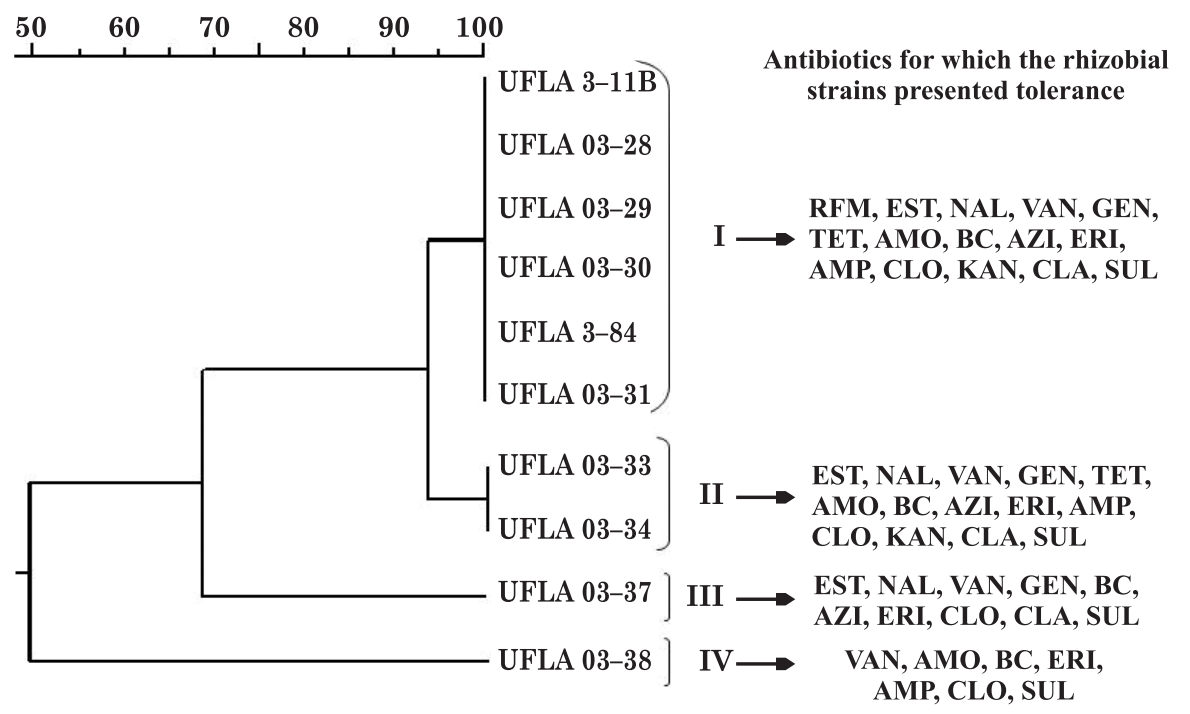

Figure 2. Dendrogram representing the relationships of the tolerance of the ten analyzed strains to the 15 antibiotics tested. amoxicillin (AMO), ampicillin (AMP), streptomycin (EST), gentamicin (GEN), azithromycin (AZI), clarithromycin (CLA), erythromycin (ERI), nalidixic acid (NAL), chloramphenicol (CLO), kanamycin (KAN), rifamycin (RFM), tetracycline (TET), vancomycin (VAN), sulfonamides (SUL) and Bacitracin (BC). Analysis was based on the UPGMA and Simple Matching (SM) algorithms.

single strain each: UFLA 03-37 and UFLA 03-38, respectively. UFLA $03-37$ was tolerant to ten antibiotics (EST, NAL, VAN, GEN, BC, AZI, ERI, CLO, CLA, and SUL), while UFLA 03-38 was tolerant to seven, the lowest number of antibiotics (VAN, AMO, BC, ERI, AMP, CLO, and SUL). While this strain established effective symbiosis with cowpea under controlled conditions, the low observed antibiotic tolerance may indicate a lesser ability to compete with native strains because studies have shown the presence of antibiotic-producing Actinobacteria populations in various soil types of Brazil (Pereira et al., 1999).

Some studies show a correlation between the growth rate and rhizobia tolerance to some antibiotics. Fast-growing strains have been shown to be more tolerant to EST, KAN, and AMP than slow-growing strains (Odee et al., 1997). Dowdle and Bohlool (1985), however, found that slow-growing strains were more tolerant to various antibiotics. Other studies found no correlation between rhizobia growth rate and antibiotic tolerance (Xavier et al., 1998; Maâtallah et al., 2002). Dowdle and Bohlool (1985) previously observed tolerance of several slow-growing rhizobia strains to some antibiotics tested in this study (EST, KAN, NAL, CLO, RFM, TET, and VAN). It is noteworthy that these authors used lower antibiotic concentrations than in the present study.

\section{Salt tolerance}

Tolerance assays for several $\mathrm{NaCl}$ concentrations in medium 79 showed that all strains were capable of growing in $86 \mathrm{mmol} \mathrm{L}^{-1} \mathrm{NaCl}$. Increasing salt concentrations prevented certain strains from growing, and no growth was observed at $684 \mathrm{mmol} \mathrm{L}^{-1}$ $\mathrm{NaCl}$ (Table 3). Only UFLA 03-29, UFLA 03-37, UFLA 03-28, UFLA 03-31, and UFLA 03-34 grew at $171 \mathrm{mM} \mathrm{NaCl}$; strains UFLA 03-38 and UFLA 0330 , which showed the greatest symbiotic efficiency with cowpea, UFLA 03-33, and the two recommended inoculant strains for cowpea were sensitive to this salt concentration and did not grow. Strain UFLA 0334 did not grow at concentrations higher than $171 \mathrm{mmol} \mathrm{L}^{-1} \mathrm{NaCl}$. Strain UFLA 03-29 showed the greatest tolerance to high salinity and grew on medium containing $513 \mathrm{mmol} \mathrm{L}^{-1} \mathrm{NaCl}$.

No correlation among the strains analyzed was detected between tolerance to high salt concentrations and symbiotic efficiency in cowpea. The sensitivity to $\mathrm{NaCl}$ was highest in strains with higher symbiotic

Table 3. Growth of Bradyrhizobium strains exposed to various $\mathrm{NaCl}$ concentrations in medium 79

\begin{tabular}{ccccccccc}
\hline & \multicolumn{1}{c}{ NaCl Concentrations $\left(\mathbf{m m o l ~ L} \mathbf{L}^{-1}\right)$} \\
\cline { 2 - 8 } & $\mathbf{8 6}$ & $\mathbf{1 7 1}$ & $\mathbf{2 5 6}$ & $\mathbf{3 4 2}$ & $\mathbf{4 2 7}$ & $\mathbf{5 1 3}$ & $\mathbf{6 8 4}$ \\
\hline UFLA $03-29$ & $+(1)$ & + & + & + & + & + & - \\
UFLA $03-37$ & + & + & + & + & - & - & - \\
UFLA 03-28 & + & + & + & + & - & - & - \\
UFLA $03-31$ & + & + & + & - & - & - & - \\
UFLA 03-34 & + & + & - & - & - & - & - \\
UFLA 03-33 & + & - & - & - & - & - & - \\
UFLA 03-38 & + & - & - & - & - & - & - \\
UFLA 03-84 & + & - & - & - & - & - & - \\
INPA 03-11B & + & - & - & - & - & - & - \\
UFLA 03-30 & + & - & - & - & - & - & - \\
(1) + growth observed, - no growth. &
\end{tabular}


efficiencies, UFLA 03-38 and UFLA 03-30, and in the strains currently recommended as inoculants for cowpea, UFLA 03-84 and INPA 03-11B. These strains did not grow at $\mathrm{NaCl}$ concentrations above $86 \mathrm{mmol} \mathrm{L}{ }^{-1}$, which could potentially limit their establishment in high salinity soils.

Previous studies indicated that rhizobia strains that produced more EPS were more tolerant to salinity (Eaglesham et al., 1987; Xavier et al., 1998; Freitas et al., 2007; Xavier et al., 2007). In this study, it was found that all strains produced medium amounts of EPS, but varied greatly in salt tolerance. Certain strains tolerate saline concentrations similar to or higher than previously reported strains originating from high saline soils of northeastern Brazil (Freitas et al., 2007; Xavier et al., 2007). These results suggest that the strains tested here could have alternative mechanisms conferring tolerance to high salinity. Alterations in cell membrane composition and trehalose production have been reported to be adaptation processes allowing rhizobia survival under saline stress conditions (Streeter, 2003; Medeot et al., 2007).

\section{Tolerance to various $\mathrm{pH}$ levels}

All of the studied Bradyrhizobium strains were able to grow at $\mathrm{pH}$ levels 4.0, 5.0, 6.0, 7.0, 8.0, and 9.0. The eight strains from southern Minas Gerais were isolated from soil samples with relatively high $\mathrm{pH}$ levels compared to average tropical soil $\mathrm{pH}$ levels (Table 1). However, this did not limit their growth in acidic conditions. Rhizobia tolerance to $\mathrm{pH}$ variation in culture media has been previously studied, and some reports indicated that there is no correlation between the $\mathrm{pH}$ of the soil from which the organism was isolated and its tolerance to media with different pH levels (Ruiz-Díez et al., 2009). However, although Bradyrhizobium strains native to tropical soils, including strain INPA 03-11B, can grow at different $\mathrm{pH}$ levels, optimal growth occurs at $\mathrm{pH}$ 6.0, indicating an adaptation to slightly acidic conditions (Miguel and Moreira, 2001). The inoculant strains UFLA 03-84 and INPA $03-11 \mathrm{~B}$ also grew at all $\mathrm{pH}$ levels analyzed. Tolerance to different $\mathrm{pH}$ levels is a desirable characteristic for potentially commercial inoculant strains.

\section{Tolerance to high temperatures}

All strains grew at temperatures of 28 and $36{ }^{\circ} \mathrm{C}$, and none grew at $45^{\circ} \mathrm{C}$. This finding was not surprising because it has been previously reported that temperatures above $40^{\circ} \mathrm{C}$ inhibit rhizobia growth (Osa-Afiana and Alexander, 1982; Maâtallah et al., 2002). Only the strains UFLA 03-84 and UFLA 0337 were not tolerant to $40{ }^{\circ} \mathrm{C}$. In the tropics, the surface soil layer of $0-20 \mathrm{~cm}$ can reach temperatures above $40^{\circ} \mathrm{C}$ (Hafeez et al., 1991). Thus, our results suggest that only soils with temperatures below $40^{\circ} \mathrm{C}$ are suitable for cowpea seed inoculation with strain
UFLA 03-84. Alternatively, INPA 03-11B, the other recommended inoculant strain, and strains UFLA 0330 and UFLA 03-38 isolated from soil samples from southern Minas Gerais state and with high symbiotic efficiency in cowpea, grew at $40^{\circ} \mathrm{C}$. Recent reports documented good performance of the inoculant strain INPA 03-11B in soils of northeastern Brazil (Costa et al., 2009, Nóbrega, personal communication). These results obtained in the field support the in vitro results presented here.

\section{Genotypic, symbiotic and phenotypic variability according to strain origin}

The performance in phenotypic and genotypic tests, as well as in symbiotic efficiency of all strains, regardless of the soil characteristics and/or nodule of origin on the plant, was variable. With one exception, it was not possible to establish a correlation between the test results and origin of the isolates. The highest genetic similarity was observed between strains UFLA 03-33 and UFLA 03-38, which were isolated from distinct nodules of the same plant originating from a soil sample from Ribeirão Vermelho (Table 1). These strains also belonged to the same groups regarding relative efficiency and tolerance to high salinity and temperatures.

Symbiotic efficiency was measured as the ability to fix $\mathrm{N}_{2}$ in symbiosis with cowpea. Strains from soil in three locations were found that supported shoot development more efficiently than the control treatment where mineral $\mathrm{N}$ was added to a nutrient solution, in which a relative efficiency value of $100 \%$ was determined. The variability in the $\mathrm{N}_{2}$ fixation capacity of the strains was high, even among those obtained from different nodules of the same plant. These results suggest that studies aimed at selecting efficient $\mathrm{N}_{2}$-fixing strains from isolates using cowpea as trap plant should analyze the largest possible number of isolates to compensate for this high variability.

Despite their origin from soils with high $\mathrm{pH}$ variation ( $\mathrm{pH} 5.3$ to 7.3 ) and from different climates, the tests showed greatest homogeneity of the analyzed strains in the characteristics tolerance to $\mathrm{pH}$, high salinity, and high temperatures (Table 1). Great variability was observed in the antibiotic tolerance among strains originating from different soil samples, as well as those isolated from the same plant. Similar variability in antibiotic tolerance was previously reported for rhizobia strains obtained from soils of northeastern Brazil (Xavier et al., 1998); however, Xavier et al. (1998) found a correlation between the soil $\mathrm{pH}$ from where the strains were isolated and their tolerance to antibiotics. Despite the small number of isolates analyzed, no such correlation was found in this study. Two strains isolated from low $\mathrm{pH}$ soil from the Amazon and four strains isolated from high $\mathrm{pH}$ soil from southern Minas Gerais were tolerant to all antibiotics tested. The performance of the strains regarding tolerance to high salinity was variable. 
Table 4. Correlation between rhizobia strain origin and their genotypic and phenotypic characteristics and symbiotic efficiencies

\begin{tabular}{|c|c|c|c|c|c|c|c|c|c|c|}
\hline \multirow{4}{*}{ Characteristics } & \multicolumn{10}{|c|}{ Strain origin } \\
\hline & \multicolumn{6}{|c|}{ Ribeirão Vermelho } & \multicolumn{2}{|c|}{ Nepomuceno } & \multicolumn{2}{|c|}{ Amazônia } \\
\hline & \multicolumn{8}{|c|}{ UFLA $03 \quad \ldots$} & \multirow{2}{*}{$\begin{array}{l}\text { UFLA } \\
\text { 03-84 }\end{array}$} & \multirow{2}{*}{$\begin{array}{c}\text { INPA } \\
03-11 B\end{array}$} \\
\hline & 38 & 33 & 29 & 37 & 28 & 34 & 30 & 31 & & \\
\hline \multicolumn{11}{|l|}{ Genetic similarity (\%) } \\
\hline 10 & + & + & + & + & + & + & + & + & + & + \\
\hline 25 & + & + & + & - & + & + & + & + & - & + \\
\hline 40 & + & + & - & - & + & + & + & + & - & + \\
\hline 50 & + & + & - & - & - & - & + & + & - & + \\
\hline 65 & + & + & - & - & - & - & - & - & - & - \\
\hline \multicolumn{11}{|c|}{$\begin{array}{l}\mathrm{N}_{2} \text {-fixing relative efficiency (\%) in } \\
\text { symbiosis with cowpea }^{(1)}\end{array}$} \\
\hline Lower than 50 & - & - & - & + & - & - & - & - & - & - \\
\hline 51 to 75 & - & - & + & - & + & - & - & + & - & - \\
\hline 76 to 100 & - & - & - & - & - & + & - & - & - & - \\
\hline 101 to 150 & + & + & - & - & - & - & . & . & + & + \\
\hline Higher than 151 & - & - & - & - & - & - & + & - & - & - \\
\hline \multicolumn{11}{|c|}{ Number of antibiotics tolerated } \\
\hline 15 & - & - & + & - & + & - & + & + & + & + \\
\hline 14 & - & + & - & - & - & + & - & - & - & - \\
\hline 10 & - & - & - & + & - & - & . & . & - & . \\
\hline 7 & + & - & - & - & - & - & - & - & - & - \\
\hline \multicolumn{11}{|c|}{ Tolerance to salinity $\left(\mathrm{mmol} \mathrm{L}^{-1}\right)$} \\
\hline Lower than 171 & + & + & - & - & - & - & + & - & + & + \\
\hline 172 to 256 & - & - & - & - & - & + & - & - & - & - \\
\hline 257 to 342 & - & - & - & - & - & - & - & + & - & . \\
\hline 343 to 427 & - & - & - & + & + & - & - & - & - & - \\
\hline 428 to 513 & - & - & + & - & - & - & - & - & - & - \\
\hline \multicolumn{11}{|c|}{ Growth at temperatures $\left({ }^{\circ} \mathrm{C}\right)$} \\
\hline 28 e 36 & + & + & + & + & + & + & + & + & + & + \\
\hline 40 & + & + & + & - & + & + & + & + & - & + \\
\hline \multicolumn{11}{|l|}{ Growth at $\mathrm{pH}$ range } \\
\hline $4,0-9,0$ & + & + & + & + & + & + & + & + & + & + \\
\hline
\end{tabular}

\section{CONCLUSIONS}

1. There is great variability in genotype, phenotype, and symbiotic efficiency among Bradyrhizobium strains isolated from the same location.

2. In general, no correlation was observed between genotypes, phenotypes, or symbiotic efficiencies and the soil origin.

3. Of the strains analyzed, UFLA 03-38 and UFLA $03-30$ were the most efficient in $\mathrm{N}_{2}$ fixation when in symbiosis with cowpea, and it is recommendable that they remain in the selection process for additional inoculant strains for this crop. These strains were also tolerant to the widest range of antibiotics, which could indicate the ability to perform better than other strains in the presence of antagonistic organisms in the soil.

\section{ACKNOWLEDGEMENTS}

The authors are indebted to the National Council of Scientific and Technological Development (CNPq), for undergraduate, graduate and research fellowships and to FAPEMIG, for an undergraduate fellowship.

\section{LITERATURE CITED}

BERGENSEN, F.J.; BROCKWELL, J.; GIBSON, A.H. \& SCHWINGHAMER, E.A. Studies of natural populations and mutants of Bradyrhizobium in the improvement of legume inoculants. Plant Soil, 46:3-16, 1971.

CHAGAS JÚNIOR, A.F.; OLIVEIRA, L.A. \& OLIVEIRA, A.N. Caracterização fenotípica de rizóbio nativos isolados de solos da Amazônia e eficiência simbiótica em feijão caupi. Acta Sci., 32:161-169, 2010.

CHUEIRE, L.M.O.; NISHI, C.Y.M.; LOUREIRO, M.F. \& HUNGRIA, M. Identificação das estirpes de Bradyrhizobium e Rhizobium utilizadas em inoculantes comerciais para as culturas da soja e do feijoeiro pela técnica de PCR com "primers" aleatórios ou específicos. Agric. Trop., 4:80-95, 2000. 
COSTA, E.M.; MARTINS, L.V.; NÓBREGA, R.S.A.; NÓBREGA, J.C.A. \& MOREIRA, F.M.S. Eficiência de estirpes de bactérias simbióticas fixadoras de nitrogênio no crescimento e nodulação de feijão-caupi no Pólo de Produção de Bom Jesus-PI. In: CONGRESSO BRASILEIRO DE CIÊNCIA DO SOLO, 32., Fortaleza, 2009. Anais... Fortaleza, Universidade Federal do Ceará, 2009. CD-ROM.

DOWDLE , S.F. \& BOHLOOL, B.B. Predominance of fastgrowing Rhizobium japonicum in a soybean field in the People's Republic of China. Appl. Environ. Microbiol., 50:1171-1176, 1985 .

EAGLESHAM, A.R.J.; STOWERS, M.D.; MAINA, M.L.; GOLDMAN, B.J.; SINCLAIR, M.J. \& AYANABA, A. Physiological and biochemical aspects of diversity of Bradyrhizobium sp. (Vigna) from three West African soils. Soil Biol. Biochem., 19:575-581, 1987.

FLORENTINO, L.A. Relações simbióticas e edáficas de Azorhizobium doebereinerae e de outras espécies nodulíferas em solos coletados próximos ao sistema radicular de Sesbania virgata (Cav.) Pers. Lavras, Universidade Federal de Lavras, 2007. 62p. (Tese de Mestrado)

FLORENTINO, L.A.; GUIMARÃES, A.P.; RUFINI, M.; SILVA, K. \& MOREIRA, F.M.S. Sesbania virgata stimulates the occurrence of its microsymbiont in soils but does not inhibit microsymbionts of other species. Sci. Agric., 66:667-676, 2009.

FRED E.B. \& WAKSMAN, S.A. Laboratory manual of general microbiology - with special reference to the microorganisms of the soil. New York, McGraw-Hill Book Company, 1928. 145 p.

FREITAS, A.D.S.; VIEIRA, C.L.; SANTOS, C.E.R.S.; STAMFORD, N.P. \& LYRA, M.C.C.P. Caracterização de rizóbios isolados de jacatupé cultivado em solo salino do Estado de Pernambuco. Bragantia, 66:497-504, 2007.

FREIRE-FILHO, F.R.; RIBEIRO, V.Q.; BARRETO, P.D. \& SANTOS, A.P. Melhoramento genético. In: FREIRE FILHO, F.R.; LIMA, J.A.A. \& RIBEIRO, V.Q., eds. Feijãocaupi: Avanços tecnológicos. Brasília, Embrapa Informação Tecnológica, 2005. 519p.

HAFEEZ, F.Y.; ASAD, S. \& MALIK, K.A. The effect of high temperature on Vigna radiata nodulation and growth with different bradyrhizobial strains. Environ. Exp. Bot., 31:85-294, 1991.

HOAGLAND, D.R. \& ARNON, D.T. The water culture method for growing plants without soil. Berkeley, University of California, 1950. 32p. (Circular, 347)

JORDAN, D.C. Transfer of Rhizobium japonicum Buchanan 1980 to Bradyrhizobium gen.nov., a genus of slowgrowing, root nodule bacteria from leguminous plants. Intern. J. Bot., 32:136-139, 1982.

LACERDA, A.M.; MOREIRA, F.M.S.; ANDRADE, M.J.B. \& SOARES, A.L.L. Efeito de estirpes de rizóbio sobre a nodulação e produtividade do feijão-caupi. R. Ceres, 51:6782,2004 .
LAGUERRE, G.; MAVINGUI, P.; ALLARD, M.R.; CHARNAY, M.P.; LOUVRIER, P.; MAZURIER S.I.; RIGOTTIERGOIS, L. \& AMARGER, N. Typing of rhizobia by PCR DNA fingerprinting and PCR-restriction fragment length polymorphism analysis of chromosomal and symbiotic gene regions: Application to Rhizobium leguminosarum and its different biovars. Appl. Environ. Microbiol., 62:2029-2036, 1996.

LAGUERRE, G.; van BERKUM, P.; AMARGER, N. \& PREVOST, D. Genetic diversity of rhizobial symbionts isolated from legume species within the genera Astragalus, Oxytropis, and Onobrychis. Appl. Environ. Microbiol., 63:4748-4758, 1997.

LIMA, A.S.; PEREIRA, J.P.A.R. \& MOREIRA, F.M.S. Diversidade fenotípica e eficiência simbiótica de estirpes de Bradyrhizobium spp. de solos da Amazônia. Pesq. Agropec. Bras., 40:1095-1104, 2005.

MAÂTALLAH, J.; BERRAHO, E.B.; MUÑOZ, S.; SANJUAN, J. \& LLUCH, C. Phenotypic and molecular characterization of chickpea rhizobia isolated from different areas of Morocco. J. Appl. Microbiol., 93:531540, 2002 .

MARTINS, L.M.V.; XAVIER, G.R.; RANGEL, F.W.; RIBEIRO, J.R.A.; NEVES, M.C.P.; MORGADO, L.B. \& RUMJANEK, N.G. Contribution of biological nitrogen fixation to cowpea: A strategy for improving grain yield in the SemiArid Region of Brazil. Biol. Fert. Soils, 38:333-339, 2003.

MATSUDA, A.; MOREIRA, F.M.S. \& SIQUEIRA, J.O. Tolerância de rizóbios de diferentes procedências ao zinco, cobre e cádmio. Pesq. Agropec. Bras., 37:343-355, 2002.

MEDEIROS, E.D.; SILVA, K.J.P.; MARTINS, C.M. \& BORGES, W.L. Tolerância de bactérias fixadoras de nitrogênio provenientes de municípios do Rio Grande do Norte à temperatura e salinidade. R. Biol. Ci. Terra, 7:160-168, 2007.

MEDEOT, D.B.; BUENO, M.A.; DARDANELLI, M.S. \& LEMA, M.G. Adaptational changes in lipids of Bradyrhizobium SEMIA 6144 nodulating peanut as a response to growth temperature and salinity. Curr. Microbiol., 54:31-35, 2007.

MELO, F.B.; CARDOSO, M.J. \& SALVIANO, A.A.C. Fertilidade do solo e adubação. In: FREIRE FILHO, F.R.; LIMA, J.A.A. \& RIBEIRO V.Q., eds. Feijão-caupi; Avanços tecnológicos. Brasília, Embrapa, 2005. 519p.

MIGUEL, D.L. \& MOREIRA, F.M.S. influência do pH do meio de cultivo e da turfa no comportamento de estirpes de Bradyrhizobium. R. Bras. Ci. Solo, 25:873-883, 2001.

MOREIRA, F.M.S. Estirpes de bactérias altamente eficientes que fornecem nitrogênio para o caupi foram selecionadas na UFLA e já são recomendadas para a produção de inoculantes comerciais. Lavras, Universidade Federal de Lavras, 2005. 12p. Disponível em: <www.ufla.br/editora/ publicações/boletim de extensão>. (Boletim de Extensão da UFLA). Acesso em: 19 abr. 2006.

MOREIRA, F.M.S. Bactérias fixadoras de nitrogênio. In: MOREIRA, F.M.S.; SIQUEIRA, J.O. \& BRUSSAARD, L., eds. Biodiversidade do solo em ecossistemas brasileiros. Lavras, Universidade Federal de Lavras, 2008. p.631-680. 
MOREIRA, F.M.S. \& SIQUEIRA, J.O. Microbiologia e bioquímica do solo. Lavras, Universidade Federal de Lavras, 2006. 729p.

MOSCHETTI, G.; PELUSOA, A.; PROTOPAPA, A.; ANASTASIOA, M.; PEPE, O. \& DEFEZ, R. Use of nodulation pattern, stress tolerance, nodC gene amplification, RAPD-PCR and RFLP-16S rDNA analysis to discriminate genotypes of Rhizobium leguminosarum biovar viciae. Syst. Appl Microbiol., 28:619-631, 2005.

NÓBREGA, R.S.A.; MOREIRA, F.M.S.; SIQUEIRA, J.O. \& LIMA, A.S. Caracterização fenotípica e diversidade de bactérias diazotróficas associativas isoladas de solos em reabilitação após a mineração de bauxita. R. Bras. Ci. Solo, 28:269-279, 2004.

ODEE, D.W.; SUTHERLAND, J.M.; MAKATIANI, E.T.; MCINROY, S.G. \& SPRENT, J.I. Phenotypic characteristics and composition of rhizobia associated with woody legumes growing in diverse Kenyan conditions. Plant Soil, 188:65-75, 1997.

OSA-AFIANA, L.O. \& ALEXANDER, M. Differences among cowpea rhizobia in tolerance to high temperature and desiccation in soil. Appl. Environ. Microbiol., 43:435-439, 1982.

PEREIRA, J.C.; NEVES, M.C.P. \& DROZDOWICZ, A Influência da antibiose exercida por actinomicetos às estirpes de Bradyrhizobium spp., na nodulação da soja. Pesq. Agropec. Bras., 34:99-108, 1999.

PIAUÍ. Governo do Estado. Disponível em: <http:// www.pi.gov.br/materia.php?id $=29815 \&$ pes $=$ caupi $>$ Acesso em 21 abr. de 2010

REGITANO, J.B. \& LEAL, R.M.P. Comportamento e impacto ambiental de anbtibióticos usados na produção animal brasileira. R. Bras. Ci. Solo, 34:601-616, 2010.

RUIZ-DÍEZ, B.; FAJARDO, S.; PUERTAS-MEJÍA, M.A.; FELIPE, M.D.R. \& FERNÁNDEZ-PASCUAL, M. Stress tolerance, genetic analysis and symbiotic properties of root-nodulating bacteria isolated from Mediterranean leguminous shrubs in Central Spain. Arch. Microbiol., 191:35-46, 2009.

SARRUGE, J.R. \& HAAG, H.P. Análises químicas em plantas. Piracicaba, Escola Superior de Agricultura "Luiz de Queiroz", 1979. 27p.
SOARES, A.L.L.; PEREIRA, J.P.A.R.; FERREIRA, P.A.A.; VALE, H.M.M.; LIMA, A.S.; ANDRADE, M.J.B. \& MOREIRA, F.M.S. Eficiência agronômica de rizóbios selecionados e diversidade de populações nativas nodulíferas em perdões (MG). I. Feijão-caupi. R. Bras. Ci. Solo, 30:795-802, 2006.

STREETER, J.G. Effect of trehalose on survival of Bradyrhizobium japonicum during desiccation. J. Appl. Microbiol., 95:484-491, 2003.

TRANNIN, I.C.B.; MOREIRA, F.M.S.; SIQUEIRA, J.O. \& LIMA, A. Tolerância de estirpes e isolados de Bradyrhizobium e Azorhizobium a zinco, cádmio e cobre in vitro. R. Bras. Ci. Solo, 25:305-316, 2001.

VERSALOVIC, J.; SCHNEIDER, M.; DE BRUIJN, F.J. \& LUPSKI, J.R. Genomic fingerprinting of bacteria using repetitive sequence-based polymerase chain reaction. Meth. Molec. Cell. Biol., 5:25-40, 1994.

VERSALOVIC, J.; DE BRUIJIN, F.J. \& LUPSKI, J.R. Repetitive sequence-based PCR (rep-PCR)DNA fingerprinting of bacterial genomes. In: DE BRUJIN, F.J.; LUPSKI, J.R. \& WEINSTOCK, G.M., eds. Bacterial genomes: Physical structure and analysis. New York, Chapman and Hall, 1998. p.437-454.

VINCENT, J.M.A. Manual for the practical study of root-nodule bacteria. Oxford, Blackwell Scientific Publications, 1970. 164p. (IBP Handbook, 15)

XAVIER, G.R.; MARTINS, L.M.V.; NEVES, M.C.P. \& RUMJANEK, N.G. Edaphic factors as determinants for the distribution of intrinsic antibiotic resistance in a cowpea, rhizobia population. Biol. Fert. Soils., 27:386-392, 1998.

XAVIER, G.R.; MARTINS, L.M.; RUMJANEK, N.G. \& NEVES, M.C.P. Tolerância de rizóbio de feijão-caupi à salinidade e à temperatura em condição in vitro. Caatinga, 20:1-9, 2007.

WEI, G.H.; ZHANG, Z.X.; CHEN, C.; CHEN, W.M. \& JU, W.T. Phenotypic and genetic diversity of rhizobia isolated from nodules of the legume genera Astragalus, Lespedeza and Hedysarum in northwestern China. Microbiol. Res., 163:651-662, 2008.

ZERHARI, K.; AURAG, J.; KHBAYA, B.; KHARCHAF, D. \& FILALI-MALTOUF, A. Phenotypic characteristics of rhizobia isolates nodulating Acacia species in the arid and Saharan regions of Morocco. Lett. Appl. Microbiol., 30:351-357, 2000. 